\title{
Nepal's REDD+ Readiness Preparation and Multi-Stakeholder Consultation Challenges
}

\author{
Rishi R. Bastakoti ${ }^{1}$ and Conny Davidsen ${ }^{2}$ \\ ${ }^{1,2}$ Department of Geography, University of Calgary-Canada \\ Corresponding author: rrbastak@ucalgary.ca
}

\begin{abstract}
Nepal is currently undergoing a Reducing Emission from Deforestation and Forest Degradation, sustainable management of forest, and conservation and enhancement of carbon (REDD+) readiness process. The Government of Nepal has announced a high level political commitment, willingness and preparedness to attract diverse interests in policy deliberation for its REDD+ process. This paper examines Nepal's REDD+ policy deliberation process from a political ecology perspective, focusing on expressions of discursive power and representation within Nepal's ongoing multi-stakeholder REDD+ preparation. The analysis is based on interviews, policy document reviews and observations of public consultations to solicit comments for REDD+ strategy during the year 2013-2014. The analysis found that Nepal's institutional REDD+ planning structure is highly dominated by techno-bureaucratic topdown practices representing government interests and international donors' requirements, while subnational and non-governmental stakeholders often find themselves to be merely used to legitimize the policy process rather than to actively shape it. A considerable share of policy preparations is left to the outsourced experts, and the multi-stakeholder consultation meetings have proven to be ineffective to bring the weak actors' perspectives that actually participate in those meetings. Both the 'geographical space' and 'political space' offered in the consultations are not favourable for the local actors, but are controlled by the dominant actors. Overall, our analysis highlights important challenges and an urgent need to improve design and practice of the consultation process in order to ensure a sound multistakeholder process so as to meet the demands of the local forest realities as well as those of the international REDD+ requirements.
\end{abstract}

Key words: REDD+, multi-stakeholder, policy process, consultation, institutions

\section{INTRODUCTION}

As the international Reducing Emission from Deforestation and Forest Degradation, sustainable management of forest, and conservation and enhancement of carbon $(\mathrm{REDD}+)$ architecture is being negotiated as a part of post-Kyoto climate agreements, many bilateral and multi-lateral initiatives are already underway to support developing countries to be ready for the same (Angelsen and McNeill 2012). Public discourse on Reducing Emission from Deforestation and Forest Degradation (REDD+) has triggered many debates on how REDD+ mechanisms should be designed and implemented, particularly regarding benefit sharing (Costenbader 2011; Noordwijk et al. 2008; Peskett and Brodnig 2011), social and environmental benefits (Schroeder and Mcdermott 2014; Somorin et al. 2014), participation (Lawlor et al. 2013; Paudel et al. 2014; Pham et al. 2014), and rights of local and indigenous people (Bastakoti and Davidsen 2014, Larson et al. 2013).
Nepalis amongthose countries thatare currently undergoing a REDD+ Readiness process with considerable amount of multi-lateral and bilateral international support. REDD+ "roadmaps" determine required interventions, institutional and policy arrangements (UNREDD 2011). Stakeholders' participation and engagement are considered critical for REDD+ strategies and implementation frameworks that are viable (Daviet 2011). The United Nation's Framework Convention on Climate Change (UNFCCC) further specifies that parties must promote education, training and public awareness that encourage the participation of a wide range of stakeholders including indigenous people, women and nongovernmental organizations. As a prerequisite, national REDD+ process needs to represent multi-actors and multi-level governance in action, which demands more inclusive, participatory form of policy formulation 
moving away from government-centered policy process (Forsyth 2009). However, the actors involved are likely to differ a great deal in their interests and understanding on different issues regarding the REDD+ policies. The extent to which the actors are heard and their issues and choices are reflected in the policies depends on how they are represented in the policy fora, their socio-political hierarchy and the institution that defines the rules of game for the policy process (Arts and Buizer 2009; Peskett and Brockhaus 2009).

The Government of Nepal (GoN) has announced a high-level political commitment, willingness and preparedness for its REDD+ process (GoN 2010). The REDD+ implementation centre has been implementing REDD+ Readiness Preparation Proposal (R-PP) whose milestones are summarized in figure 1.

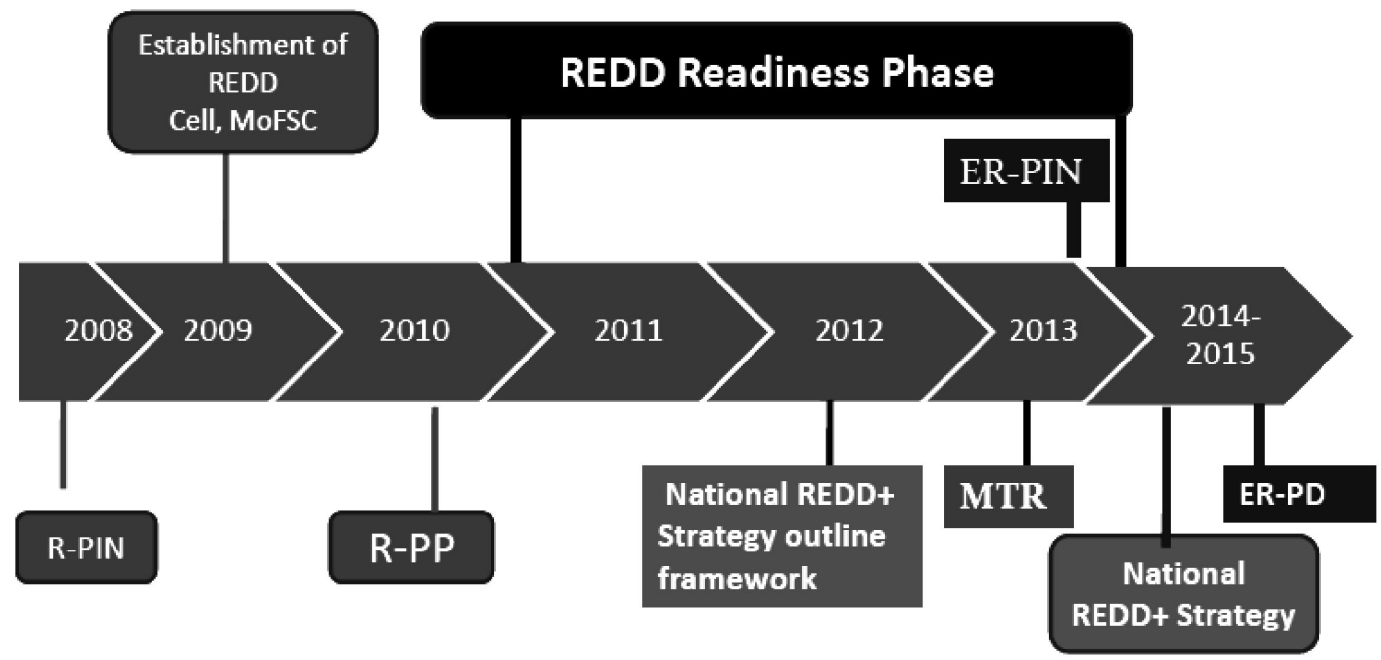

Figure 1: National REDD+ Readiness Landscape

(Adapted from Chand 2014)

Multi-stakeholder consultation is explicitly emphasized in the roadmap as an important contributor 'to promote a transparent, inclusive, accountable, equitable and ecologically sustainable implementation of REDD in Nepal' (GoN 2010: 22). However, recent research on REDD+ implementation processes in practice indicates that the central governance issues such as tenure, benefit sharing, and local engagement are often not adequately addressed, despite their crucial roles for the success of REDD+ (Davis et al. 2009; Bushley 2010). Furthermore, the local forest communities' level of knowledge and consultation about forest carbon offset mechanisms, its processes and consequences often remains very low (Bastakoti 2014; Bastakoti and Davidsen 2014), and forest actors including government and other project implementers lack the strategies and responsibilities to make REDD+ initiatives more inclusive (Khadka et al. 2014). Subsequently, it has been suggested that the views and interests of the weak and marginalized actors have been repeatedly hampering the effective implementation of REDD+ in the country (Bushley 2014).

This paper examines the above-mentioned issues of Nepal's ongoing policy deliberation process through a political ecology 
perspective. ${ }^{1}$ It is focused to help understand the actors and the power they hold; and how the historical contexts and the interests of the various actors with varying agendas shape the current natural resource policies, institutional frameworks and practices. It also looks at how they affect local access to natural resources and how some interests are marginalized and others are enhanced by the state and the other powerful actors (Barrow et al. 2002; Jones 2006). It provides insights about the extent to which policy derivatives of REDD+ discourse represent local realities and interests surrounding local livelihoods and global environmental services. It further offers deeper insights about how the new discourse of carbon trade has gained priority in forest policy, and how it has managed to reconfigure the relationship between environmental conservation and livelihoods (Bastakoti and Davidsen 2014).

The analysis in this research centers on a Foucauldian notion of power that enables a focus on expressions of discursive power and representation within the ongoing REDD+ preparation and multi-stakeholder consultation. Power in this context is not understood as a fixed entity, structure or institution, but is instead, relational, i.e. a result of social processes and realized through the social institutions. As such, the study examines institutional settings and the actor-related policy process within the dynamic policy arena in practice. REDD+'s institutional setting is captured here as the related set of the formal and informal regulations, rules and norms that are established over time (Baumgartner et al. 2011; North 1990; Ostrom 1990; Scharpf 2000). The 'policy arena' of the process, in comparison, encompasses the larger platform created by the institutional setting, but shaped by its actors ranging from individuals, communities and organizations to larger networks which can foster or prevent certain policies and influence policy formulation (Arts 2012; Scharpf 1997). This approach builds on the idea that a country's specific mix of actors and its institutional contexts are critical for the success of REDD+. It allows this analysis to examine the participation of stakeholders in Nepal's ongoing policy process and REDD+ debates at the national and sub-national levels with a particular emphasis on the quality of multi-scale and de facto interaction among actors.

The analysis is based on interviews, policy document reviews and personal observations held in Kathmandu and several local forest communities from December, 2013 to September, 2014 (fieldwork conducted by the first author). These were conducted when public consultations to solicit comments on Emission Reduction- Program Idea Notes (ER-PIN), Strategic Environmental and Social Assessment (SESA) and National REDD+ Strategywere underway. A total of 77 interviews were conducted across national and regional governments, national and international nongovernmental organizations and research organizations, civil society representatives and individuals within local forestry groups. All the interviews were conducted using a semistructured or unstructured conversational approach in order to allow for a deeper probing on the important issues, and concerns regarding REDD+ and its consultation process. The data is complemented by literature analysis of the extensive documentation of Nepal's REDD+ policy process, describing in detail required procedures and de facto implementations of workshops, national dialogues, and project meetings by government actors, research institutions, and series of consultations meetings organized for the preparation of Nepal's National REDD+ Strategy. Additionally, journal papers and 'gray' literatures were also reviewed.

${ }^{1}$ Political ecology research has long called for a deeper engagement with natural resource conservation as a social process with significant political dimensions driven by the vertical and horizontal interplay of actors. It is further determined by the conflict between elite and poor, state and community, or outsider and local communities (Escobar 2008; Vaccaro and Beltran 2010). It focuses on the role of power relations, resource interests and societal norms in order to scrutinize policy processes for their influence on, and by environmental issues based on an understanding that the nature-society interface is inevitably political (Davidsen 2010). 
STAKEHOLDER ENGAGEMENT, POWER AND CONSULTATION: THE CHALLENGES

\section{Governmental REDD+ Structures}

National governance on REDD+ refers to all institutions, processes, and decisionmaking mechanisms that enable the country to channel resources from the international to the local level while addressing the drivers of deforestation (GoN 2010) and ensuring the social and environmental safeguards (UNREDD 2011). The Nepal government has established a three-tiered structure to govern REDD+ in this regard:

(1) The Apex Body is the highest entity, and the one in charge of policy-making power. It consists of an inter-ministerial, governmental stakeholder committee chaired by Nepal's Ministry of Forests and Soil Conservation (MoFSC) for the coordination and monitoring of REDD+ related policy planning process across eleven national ministries and the National Planning Commission. Each ministry is further able to invite two representatives from the private sector, and civil society organizations, making the Apex Body a total number of 49 members.

(2) The REDD+ Working Group (RWG) formed under the chair of MoFSC secretary supports the Apex Body on the operational level. The Working Group has 12 individuals who are selected by the MoFSC, with nine from governmental agencies, one from a donor agency, and two from civil society backgrounds.

(3) Furthermore, the REDD Forestry and Climate Change Cell (recently re-named REDD Implementation Center - REDDIC) is the administrative support body within the MoFSC that coordinates and implements REDD+ management, consultation and research activities at the national and subnational levels among diverse stakeholders across the country. It consists of four sub-sections: a) the Policy and Program Development section that develops REDD+ related forestry policies and monitors their implementation; b) the Monitoring, Reporting and Verification Section that develops reference baselines, monitoring and verification system, and carbon accounting system; c) the Extension and Outreach Section that takes the lead in designing and disseminating REDD+ information, extension and capacity building activities for stakeholders and also provides feedback to the REDD-IC throughout the process; and d) the Financial and Administration Section that leads the budget management including control and approval of financial plans and support to program planning and implementation.

\section{Apex Body: Challenges}

The Apex Body has not been fully using its potential and assigned role for Nepal's REDD+ preparations. Instead, it has been criticized for lacking proactive leadership, funding support, and interest due to its internal composition, limited activities and communication

The Apex Body is formally supposed to meet twice a year, but it has in fact only met two times in total since its formation in September, 2010 (MoFSC 2013). In our interviews, government officials explained the reason for this is because of the lack of focus on the urgent issues on the agenda, but non-governmental REDD+ experts have criticized the effectiveness of the Apex Body as insufficiently proactive and unable to lead and provide direction on the REDD+ policy process.

Even when there are meetings scheduled, our data indicates that the Apex Chair's attendance is not regular. It is the same case with the representatives from outside the MoFSC and also non-forest ministries. As the nonforest ministries seem to be less interested in REDD+, rather cross-sectoral impacts of climate change would be a better interest for them. As Paudel et al. (2013) found that the high-level institutional representative heads on 
such committee can be counter-productive in a multi-stakeholder and multi-sectoral forum as they often do not have the time and detailed engagement in the ongoing REDD+ process. This may result in faulty consensus across institutions without sufficient understanding about the issues at hand, and it may even reduce the role of such policy forum to one of the political legitimacy rather than the actual policy merit.

\section{REDD Working Group: Challenges}

By design and in practice, the RWG has a much higher level of activity than the Apex Body, to whom it reports. Its role is to work on the innovative recommendations, monitor program activities and facilitate overall development of a comprehensive REDD+ strategy (MoFSC 2013). The RWG meets every two months and its members are expected to allocate fifty days per year to it (GoN 2010).

Our data suggest a few major challenges or concerns for the RWG: First, the MoFSC dominates representation (representing 9 out of 12), with very few non-governmental stakeholders and none from the private sector. More marginalized and forest dependent groups such as lower-caste Dalits, women and landless groups are left out on this process. Our review of the Working Group meeting minutes shows that other external observers have been invited to the selected meetings in the past, but they are usually further bureaucratic experts, influential donors, international organizations and consultancy agencies. Interviews have raised the issue that the process of inviting observers and selecting consultants for key contributions often remains very ambiguous and non-transparent, to the extent that any existing alliances and dependencies with government bodies, donors and influential international non-governmental organizations remain hidden. Furthermore, even the two national forests and indigenous civil society organizations that are members have found themselves unable to make their voice heard effectively. Our interviews indicate that these civil society members were in several cases not involved in - or not even informed of- the crucial decisions. Instead appeared to be used in retrospect as 'multi-stakeholder' instruments on paper to endorse decisions that had already been made. In fact, as observed in the previous studies (Khatri and Paudel 2013), the forum has been an instrument for legitimizing government's policy decisions rather than a functional multi-stakeholder forum.

\section{REDD Implementation Center: Challenges}

Similar to concerns identified for the RWG above, our interviews and other data review indicate that REDD-IC has considerable limitations resulting from its design, due to its highly bureaucratic composition that usually favors a top-down and technocratic worldview. Secondly, institutional embeddedness has been found to severely hinder its effectiveness and range of activities. The REDD-IC was created as a separate wing of the MoFSC, making it largely isolated within the ministry's institutional structure and excluding it from the Ministry's existing administrative channels of communication, authority and accountability with the Ministry's regional and District Forest Offices (DFO). As a result, structurally and functionally, the REDD-IC is limited to the national level and, even within the national level, to a relatively small number of people among the government bureaucracy, development agencies and few civil society federations (see also Paudel et al. 2013). Our data shows that although capacity building of external stakeholders as well as local forestry staff is one of the major programs of REDDIC, its program has not reached down to the district level. During our field visits, we noticed that the front line of forestry officials such as Assistant Forest Officers (AFO) at the district level who are responsible for the implementation of REDD+ showed a lack of basic knowledge and training with respect to REDD+ and its mechanisms. 
Stakeholder Engagement REDD+ Consultation Process

Stakeholder participation has been identified as vital in the REDD+ policy process in search of finding more effective solutions; mitigate risks with regards to potential conflicts, and ensure the rights of the impacted groups (Daviet 2011). This focus on stakeholders explicitly acknowledges that developing and implementing REDD+ strategies is complex and is likely to impact the rights of numerous groups.

The GoN claims that its RPP was prepared in a participatory and consultative process involving local community groups, forest dependent poor, local government, NonGovernmental Organizations (NGO), community networks and professional groups (GoN 2010). However, several studies have found that consultation during the process was not effective (Bushley 2010; Paudel et al. 2013; Khatri 2012; Bastakoti and Davidsen 2014). Instead, government agencies have remained dominant in policy formulation and implementation to the extent that stakeholder participation was rather rhetoric than a reality.

Following the preparation of RPP, Nepal's REDD+ landscape of policy actors changed. Some withdrew or declined interest in further participation, while new actors emerged (Paudel et al. 2013). As part of the REDD+ readiness process, state and non-state actors had been implementing different capacity building, research and policy formulation activities. The REDD-IC hired consulting firms to establish Reference of Emission Levels (REL) and a Monitoring Reporting and Verification (MRV) systems, conduct a Strategic Environmental and Social Assessment (SESA) and Environmental and Social Management Framework (ESMF) and; work on the National REDD+ Strategy. In this context, our data review strongly suggests that Nepal's REDD network is dominated by the entrenched interest of powerful actors especially forestry bureaucrats, consultants, experts and donor agencies (Khatri et al. 2013; Khatri 2012), largely excluding the interest of marginalized groups and forest dependent people. Described below is a selected anecdotal account of limited actual actor engagement during the SESA preparation and National REDD+ Strategy.

\section{SESA Process}

The SESA represent the central framework of requirements and procedures regarding social and environmental safeguards and their effective implementation on the ground. Developing SESA is usually embedded in the process of developing the overall REDD+ strategy, constituting an in-depth process that assesses possible social and environmental risks once the planned REDD+ strategies and interventions are known.

In Nepal's case, the national SESA process was pushed before the preparation of the national REDD+ strategy that limit the offer in guidance on the actual activities that could cause social and environmental impacts. It was started in September 2013 and is already completed; based on merely hypothetical scenario and developed under immense time pressure to fulfill donor requirements before the full national REDD+ strategy could be commissioned (as clarified by government authority, World Bank representative in the second National Consultation Workshop March 12, 2014). During this time, the SESA process consultation was highly limited in scale. The consulting team has admitted that they had to limit public consultations to Kathmandu and three other nearby districts due to limited budgets (MoFSC 2014: P 8). Our interviews and personal observations at the national consultation workshop in March 2014 indicate considerable dissatisfaction of stakeholders with the process and outcome of the SESA. Most of the civil society participants did not clearly understand the purpose and nature of 
SESA, and the workshop coordinators and administrators could not clearly communicate and educate its purpose, scope and possibilities to the stakeholders. Participants also raised the issues on the transparency and the ethics of public consultation, illustrated below (Box 1).

\section{Box 1}

"The organizers did not respect our rights to have accessed to the information. They invited us for consultation without giving any prior information. We don't know what to contribute. Are we coming here just to legitimize the consultants' work? If we being as forestry experts (added by the authors) are lost in the discussion and our role is just to listen what the consultants say, I wonder how the ordinary people from rural communities understand what is going to be in store for them in the name of REDD+ and how they can assess the potential advantages and disadvantages of this SESA."

- Workshop Participant; FECOFUN Representative during SESA National Workshop, March 12, 2014

The timeline and budget limitations of the SESA process were heavily critiqued throughout the interviews, especially by the civil society actors and experts from Nepal Foresters' Association. They raised issues on the validity of the process, describing an iron triangle of donor-consultant-bureaucracy alliances that were wasting limited funds on costly foreign consultants and were critiqued on excluding local interests and the voices of civil society.

\section{National REDD+ Strategy Process}

Recently, the GoN has commissioned a consultation team to develop the national REDD+ strategy. The GoN has prepared a plan to make the national REDD+ strategy process more inclusive and consultative so as to comply with the international commitments. According to the REDD+ strategy inception report, it has planned to conduct three national, five regional, and fifteen local workshops. 
The following table provides an overview consultation workshops at the national, of participants' attendance in six different regional and local levels,

Table 1: Stakeholders Participation in REDD+ Strategy Consultation Workshop

\begin{tabular}{|c|c|c|c|c|c|c|c|c|c|}
\hline 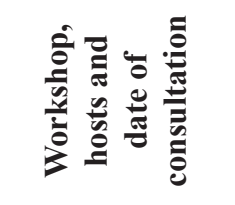 & $\stackrel{\bar{\pi}}{\stackrel{\sigma}{\theta}}$ & 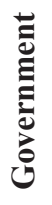 & \begin{tabular}{l}
$\mathscr{0}$ \\
\hdashline
\end{tabular} & 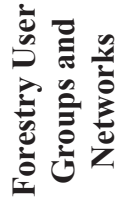 & 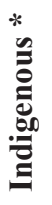 & $\frac{\sqrt[\pi]{3}}{\sum}$ & 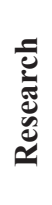 & 泀 & 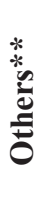 \\
\hline $\begin{array}{l}\text { National } \\
\text { Inception } \\
\text { Kathmandu } \\
\text { REDD Cell } \\
\text { August 15, } \\
2014\end{array}$ & 38 & 17 & 7 & 2 & 2 & 1 & 4 & 5 & 0 \\
\hline $\begin{array}{l}\text { Regional } \\
\text { Biratnager } \\
\text { Eastern } \\
\text { Regional } \\
\text { Forest } \\
\text { Directorate } \\
\text { September 1, } \\
2014\end{array}$ & 51 & 21 & 8 & 13 & 0 & 1 & 1 & 4 & 3 \\
\hline $\begin{array}{l}\text { Siraha } \\
\text { DFO } \\
\text { August 31, } \\
2014\end{array}$ & 20 & 7 & 3 & 5 & 1 & 2 & 0 & 2 & 0 \\
\hline $\begin{array}{l}\text { Sunsari } \\
\text { FECOFUN } \\
\text { August 31, } \\
2014\end{array}$ & 25 & 5 & 1 & 10 & 1 & 4 & 1 & 2 & 1 \\
\hline $\begin{array}{l}\text { Dhankuta } \\
\text { FECOFUN } \\
\text { September 2, } \\
2014\end{array}$ & 26 & 4 & 5 & 8 & 2 & 2 & 1 & 2 & 2 \\
\hline $\begin{array}{l}\text { Sankhuwasabha } \\
\text { DFO } \\
\text { September } 3 \text {, } \\
2014\end{array}$ & 20 & 8 & 4 & 5 & 1 & 0 & 1 & 1 & 0 \\
\hline
\end{tabular}


Usually, either the forest administration or Federation of Community Forestry Users Nepal (FECOFUN) hosted local consultation, which seemed to affect the number of attendees from their respective circles. The participant selection criteria were not clear. However, the government and community forestry network were well represented whereas a diverse range of rights-holders ${ }^{2}$ including women, dalits, indigenous, landless, forest dependent groups and private forest growers were underrepresented (see Table 2). Attendance data and observation indicates that the workshop participants mostly reflected the planners' professional 'field of vision' rather than the real stakeholders (Box 2).

Table 2. Women and Dalit Representation in Consultation Workshops at Different Level

\begin{tabular}{lllllll}
\hline Workshop & National & Eastern Region & Siraha & Sunsari & Dhankuta & Sankhuwashabha \\
\hline Total & 38 & 51 & 20 & 25 & 26 & 20 \\
Women & 3 & 5 & 0 & 1 & 4 & 1 \\
Dalit & 1 & 1 & 0 & 0 & 2 & 0 \\
\hline
\end{tabular}

Source: Compiled field observation, 2014

\section{Box 2}

"Within a limited time, we had a good discussion and collected feedbacks from different perspectives. However, important right-holders have been left out of today's discussion. It seems, we could not differentiate between stakeholders and rights-holders. Now, the main concern is how to bring the issue of right-holders in the national strategy."

- Dr. Dilli Raj Khanal (REDD+ strategy consultancy team member, commenting after attending the district level workshop in Sunsari) August 31, 2014

The commissioned consultancy team for these consultations fromKathmanduwouldaskalocal host to invite participants for the workshop on a short notice. We found that neither the local host nor the participants were well informed about its agenda, context or intended goals before the workshop. These meetings usually lasted half a day, over which the consultancy team sought feedback and comments following an introductory presentation. The participants were asked for feedbacks on five major areas: guiding features of REDD+, strategic options, institutional arrangement, social and environmental safeguards, and MRV. Ideally, the workshops were organized to engage local actors in analyzing the issues on REDD+, and negotiation and consensus-building around the problems defined, priority setting, REDD+ process, social and environmental impact assessment and monitoring, benefit sharing and grievance resolution mechanism.

We noticed shortcomings about the way the workshops were planned and conducted, and the roles that were assigned to the local participants. Interviewees at several workshops reported that they felt overwhelmed and dismissed because insufficient information had been provided to them before the meeting, concerning the general background of Nepal's REDD+ plans as well as concerning the current status of the process. Some participants added that these meetings were unable to go beyond basic information sharing and capacity building of stakeholders and right-holders (Box 3). Some of the workshop participants had never even heard the term REDD + before, which turned the workshop

\footnotetext{
2 'Rights-holders' are those whose existing rights, whether formally recognized or granted based on customary law, are potentially affected by the REDD+ program and 'stakeholders' are those whose interests are potentially affected by the program or who can affect and influence the program.
} 
into what it seemed like first-contact events for public outreach and capacity building for them.

\section{Box 3}

"We learnt today what REDD+ is and why and how government is preparing for REDD+ implementation. A half-day program is not enough even for being informed about things. How can we contribute without knowing the context? It would be good if we had understood the context before you had asked for our input today."

\section{- District FECOFUN leader during the workshop,} Sunsari August 31, 2014

Many of the more informed and engaged participants interviewed at the workshops further criticized that, while welcoming the general idea of a consultation process toward a multi-stakeholder forum for feedback and input for Nepal's REDD+ strategy, the current workshop practices would violate the consultation principles of free prior and informed consent (FPIC). This is because participants were not provided adequate time and information to truly participate in the consultation, and were not given the chance to prepare for an actual exchange of opinion with the planning authority. Without FPIC, it is not possible to minimize the negative impacts or possible to harness the benefits from REDD+ (Sherpa and Rai 2013). As a possible way forward, several interviewees urged for additional efforts toward local stakeholder engagement through a two-way dialogue on REDD+ strategy development. They also emphasized that interested stakeholders should have the right to see the final draft report of the consultation workshops to make sure that the stakeholders' voices had been adequately reflected. Others suggested that the consultations should not be organized as a means for fulfilling of donor requirements.
Rather they should be designed to bring the real voices of forest dependent groups including marginalized and less informed groups.

\section{Box 4}

"Awareness has not reached the general public; even forestry officials from the district and local level are not familiar with REDD+ issues. REDD+ discussion has remained centralized only in Kathmandu. FECOFUN and Nepal Federation of Indigenous Nationalities (NEFIN) have done capacity building programs in some districts, but they have not reached beyond the executive level. Without adequate awareness, rightholders cannot defend their stakes nor can they contribute to the policy deliberation process."

- District Forest Officer, Morang during a regional workshop in Biratnagar, September 1, 2014

'Space' is another interesting perspective to examine the dimensions of power relationships and ineffective interaction here. The locations of consultation workshops were mostly based on a brief geographical sample and easy access from Kathmandu, rather than accommodating specific regions and interest groups of relevance; the meetings were also mostly held in larger city centers away from forest communities (Box 4). Observations during the SESA and National REDD+ strategy consultations suggest that most of the consultations were organized at the convenience of the project and participants mainly from the vicinity of the program venue. This 'geographical space' restricts the participation of communities who live far away from the district headquarters or city centers.

Moreover, the 'political space' they are invited to is not conducive for local actors due to the associated power relationships. The dominant actors such as government officials, donor agencies or experts often strategically 
controlled the workshop discussions (Ojha 2014). While theoretically it seems that spaces are opened for dialogue, representatives from local communities have been observed to barely speak up in the presence of strong actors. Such 'invited spaces' (Cornwall 2008) are inconvenient for community people for several reasons. First, the heterogeneity of participants and power relations made them feel mostly suppressed. Second, the chosen language is not generally compatible to follow and provide input for them. The first author has also observed several consultation meetings in Kathmandu that were conducted in English, which signalled a clear priority of the foreign experts while ignoring the participants (rightsholders) from the local communities. In other words, the 'invited spaces' had limited scope for local communities for effective participation. Indigenous leaders and advocates indicated the need for a different space for homogenous groups who have little power or voice in society in order to bring their voice into the policy debate.

\section{CRITICAL REFLECTION AND CONCLUSION}

This study presented an analysis on the challenges of multi-stakeholder engagement in Nepal's REDD+ preparations, based on the qualitative interview, workshop observation and policy document review. By taking a political ecological perspective, it particularly focused on the influences of the institutional setting and the de facto actor-related policy interactions in the REDD+ policy process that allows for a particular focus on the power relations between the actors in both institutional designs as well as in governance practice.

The national R-PP document announced stakeholder participation as crucial in the planning process in order to identify more effective solutions, mitigate risks with regards to potential conflicts, and specifically to ensure that the rights of affected groups are adequately taken into account (GoN 2010). The analysis however found that despite all 'political' declarations of public consultation and an open deliberative process, Nepal's institutionalarrangement for REDD + planning continues to be highly dominated by technobureaucratic top-down practices. Furthermore, the analysis also found that the representation of the government and the requirements of international donors were strong while the subnational and non-governmental stakeholders often find themselves being used to legitimize the policy process in retrospect rather than provided space to actively shape it. Moreover, the non-state actors are used as mere recipients of a basic information, rather than as active and well-informed participants consulted in a proactively and considerately planned process. As Cornwall (2008) summarized earlier, participation does not necessarily lead to influence in the process.

Furthermore, a considerable share of Nepal's $\mathrm{REDD}+$ readiness is being conducted through the outsourced consultancy experts and related requirements formulated by international funding agencies such as the World Bank and the United States Agency for International Development (USAID), which have shaped the agendas, networks, timelines and tone of the consultation process as well. The national government and international donors seem compelled to adopt a participatory governance process in order to comply with REDD's international procedural requirements. However, most of the REDD+ policy events and consultation meetings have proven to be ineffective and inadequate for engaging multi-stakeholders and incorporating their suggestions and opinions in the policies. Our review of the actor identification and mapping process, a foundation for the recent consultation phase, suggests that the informal, marginalized and less-informed stakeholders have been largely disregarded throughout the process, and systematically been shifted out of sight while the large formal institutional 
actors and the forest administration were favored and emphasized. The vulnerable forest communities, marginalized groups and even actors associated with major drivers of deforestation such as landless people, forest dependent communities, timber processing companies, mining companies and local governments who are heavily involved in the infrastructural aspects like road construction and irrigation (UN-REDD 2014) are mostly absent from national and sub-national level policy debates and consultations, and remain excluded from stakeholder recognition at the large influential forums.

Capacity building and FPIC on REDD+ among stakeholders are the other challenges that the consultation process is facing. Principally, REDD+ policy engagement requires capacity building of stakeholders to participate, identification of potential impacts of various decisions and recognition of potential conflicts (Daviet 2011). Stakeholders can contribute only if they are familiar with the issues. Capacity building is, however, considerably lagging behind while the policy formulation process is moving ahead resulting into creation of a hypocritical situation in which the rights of forest dependent groups are recognized only on paper instead of in practice (Jumbe and Angelsen 2006; Blom et al. 2010; Iversen et al. 2006; Dooley et al. 2011). Largely, the participants were neither timely informed nor provided with adequate background information about REDD+ and the consultation process, which caused part of the problem.

Our findings indicate that Nepal's current challenges in stakeholder consultation processes, both in design and practice, do not deliver the purpose and benefit that the consultations are supposed to do as envisioned in the international REDD+ procedures and requirements. As the interests of the key stakeholders (e.g., forest managing communities) are neglected, Nepal's emerging
REDD+ policy framework runs the risk of not being able to fully consider and address the main drivers of forest and carbon change (Pham et al. 2014). We strongly suggest that further research on stakeholder participation and dynamics of power relation are necessary to strengthen the ongoing development of policies regarding the institutional design as well as policy deliberation practice for Nepal's emerging REDD+ framework in order to identify the best-scenario options.

\section{ACKNOWLEDGEMENT}

The authors would like to thank the editorial team and anonymous reviewers for their valuable comments on this manuscript. The first author, Rishi R Bastakoti, is grateful to Social Science and Humanities Research Council (SSHRC), Canada for providing Vanier Canada Graduate Scholarship (Vanier CGS) for his PhD and for Canada Graduate Scholarships-Michael Smith Foreign Study Supplement (CGS-MSFSS) for the field research in Nepal.

\section{REFERENCES}

Angelsen, A. and McNeill, D. 2012. The Evolution of REDD+. In: A. Angelsen, M. Brockhaus, W.D. Sunderlin and L. Verchot (Eds.), Analysing REDD+: Challenges and Choice (pp. 31-50). CIFOR, Bogor, Indonesia.

Arts, B. 2012. Forests Policy Analysis and Theory Use: Overview and Trends. Forest Policy and Economics, 16: 7-13.

Arts, B. and M. Buizer. 2009. Forests, Discourses, Institutions: A Discursive-Institutional Analysis of Global Forest Governance. Forest Policy and Economics,11:340-347.http://dx.doi.org/10.1016/i. forpol.2008.10.004

Barrow, E., Clarke, J., Grundy, I. Jones, K. and Tessema, Y. 2002. Analysis of Stakeholder Power and Responsibilities in Community Involvement in Forest Management in Eastern and Southern Africa. Nairobi: International Union for Conservation of Nature.

Bastakoti, R. 2014. Discussion on REDD+ and Carbon Rights in Nepal (in Nepali). Hamro Ban Sampada, 11(1): 1-7.

Bastakoti, R. and Davidsen, C. 2014. REDD+ and Forest Tenure Security: Concerns in Nepal's Community forestry. International Journal of 
Sustainable Development and World Ecology, 21 (2): 168-180. doi:10.1080/13504509.2013.879542

Baumgartner, F.R., Jones, B. D. and Wilkerson, J. 2011. Comparative Studies of Policy Dynamics. Comparative Political Studies, 44: 947-972.

Blom, B., Sunderland, T. and Murdiyarso, D. 2010. Getting REDD to Work Locally: Lessons Learned from Integrated Conservation and Development Projects. Environmental Science and Policy, 13: 164 172.

Bushley, B.R. 2010. Seeing the Communities for the Carbon: Governance Challenges of Reducing Emissions from Deforestation and Forest Degradation in Nepal. Reconsidering Development, 1(1).

Bushley, B. R. 2014. REDD+ Policy Making in Nepal: Toward State-centric, Polycentric, or MarketOriented Governance? Ecology and Society, 19(3): 34 http://dx.doi.org/10.5751/ES-06853-190334

Chand, N. 2014. Progress and Challenges in Safeguard Information System - A Case of Nepal. REDD Implementation Centre, Ministry of Forest and Soil Conservation. (safeguard.jimdo.com/app/ download/9659753579/04_Mr.\%20Chand.pdf? accessed on 5 January, 2015)

Cornwall, A. 2008. Unpacking "Participation": Models, Meanings and Practices. Community Development Journal, 43(3): 269-283. doi:10.1093/cdj/bsn010

Costenbader, J. 2011. REDD+ Benefit Sharing: A Comparative Assessment of Three National Policy Approaches. Forest Carbon Partnership Facility and UN-REDD Programme.

Davidsen, C. 2010. Political Ecology. In: B. Warf (Ed.), Encyclopedia of Human Geography (pp. 2209-2214). Thousand Oaks/CA: Sage Publications.

Daviet, F. 2011. A Draft Framework for Sharing Approaches for Better Multi-stakeholder Participation Practices. Forest Carbon Partnership Facility and UN-REDD Programme.

Davis, C., Daviet, F., Nakhooda, S. and Thualt, A. 2009. Getting Ready. A Review of the World Bank Forest Carbon Partnership Facility Readiness Preparation Proposals. WRI Working Paper. Washington D.C: World Resources Institute.

Dooley, K., Griffiths, T., Martone, F. and Ozinga, S. 2011. Smoke and Mirrors: A Critical Assessment of the Forest Carbon Partnership Facility. Brussels, Belgium: FERN and TPP.

Escobar, A. 2008. Territories of Differences: Place, Movements, Life, Redes. Durham, NC: Duke University Press.

Forsyth, T. 2009. Multilevel, Multiactor Governance in REDD. In: A. Angelsen, M. Brockhaus, M. Kanninen, E. Sills, W. Sunderlin and S. WertzKanounnikoff (Eds.), Realising REDD+: National Strategy and Policy Options. CIFOR, Bogor, Indonesia.
GoN. 2010. Nepal's Readiness Preparation Proposal: REDD 2010-2013. Ministry of Forests and Soil Conservation, Government of Nepal.

Iversen, V., Chhetry, B., Francis, P., Gurung, M., Kafle, G., Pain, A. and Seeley, J. 2006. High Value Forests, Hidden Economies and Elite Capture: Evidence from Forest User Groups in Nepal's Terai. Ecological Economics, 58: 93-107.

Jones, S. 2006. A Political Ecology of Wildlife Conservation in Africa. Review of African Political Economy, 109: 483-495.

Jumbe, C.B.L. and Angelsen, A. 2006. Do the Poor Benefit from Devolution Policies? Evidence from Malawi's Forest Co-management Program. Land Economics, 82: 562-581.

Khadka, M., Karki, S., Karky, B. S., Kotru, R. and Darjee, K. B. 2014. Gender Equality Challenges to the REDD+ Initiative in Nepal. Mountain Research and Development, 34(3): 197-207.

Khatri, D.B. 2012. Is REDD+ Redefining Forest Governance in Nepal? Journal of Forest and Livelihoods, 10(1): 74-87.

Khatri, D.B. and Paudel, N.S. 2013. Is Nepal Getting Ready for REDD+? An Assessment of REDD+ Readiness Process in Nepal. Discussion Paper Series 12.2. Kathmandu: ForestAction Nepal.

Larson, A. M., Brockhaus, M., Sunderlin, W.D. Duchelle, A. Babon, A., Dokken, T., Pham, T. T., Resosudarmo, I. A. P., Selaya, G. Awono, A. and Huynh T. B. 2013. Land Tenure and REDD+: The Good, the Bad and the Ugly. Global Environmental Change, 23:678-689.

Lawlor, K., Madeira, E., Blockhus, J. and Ganz, D. 2013. Community Participation and Benefits in REDD+: A Review of Initial Outcomes and Lessons. Forests, 4(2): 296-318. doi:10.3390/ f4020296

MoFSC. 2013. Mid Term Report: World Bank FCPF Grant on REDD Readiness. A Report submitted to The World Bank/ Forest Partnership Program (FCPF) by REDD Forestry and Climate Change Cell. Ministry of Forests and Soil Conservation, Government of Nepal.

MoFSC. 2014. REDD+ SESA and ESMF Nepal REDD+ Strategic Environmental and Social Assessment. Ministry of Forests and Soil Conservation, Government of Nepal.

Noordwijk, M., Pumono, H., Peskett, L. and Setiono, B. 2008. Reducing Emissions from Deforestation and Forest Degradation (REDD) in Indonesia: Options and Challenges for Fair and Efficient Payment Distribution Mechanisms. Working Paper 81. World Agroforestry Centre, Bogor, Indonesia.

North, D. 1990. Institutions, Institutional Change and Economic Performance. Cambridge: Cambridge University Press. 
Ojha, H. R. 2014. Beyond The "Local Community": the Evolution of Multi-scale Politics in Nepal's Community Forestry Regimes. International Forestry Review, 16 (3): 339-353.

Ostrom, E. 1990. Governing the Commons: The Evolution of Institutions for Collective Action. Cambridge: Cambridge University Press.

Paudel, N. S., Khatri, D. B., and Karki, R. 2014. REDD+ Readiness in Nepal In Search of Effective Stakeholder Participation. Infobrief No. 74. CIFOR, Bogor, Indonesia.

Paudel, N.S., Khatri, D.B., Khanal, D.R. and Karki, R. 2013. The Context of REDD+ in Nepal: Drivers, Agents and Institutions. Occasional Paper 81. CIFOR, Bogor, Indonesia.

Peskett, L. and Brodnig, G. 2011. Carbon Rights in REDD+: Exploring the Implications for Poor and Vulnerable People. World Bank/REDD-net.

Peskett, L. and Brockhaus. M. 2009. When REDD+ Goes National: a Review of Realities, Opportunities and Challenges. In: A. Angelsen, M. Brockhaus, M. Kanninen, E. Sills, W. D. Sunderlin, and S. WertzKanounnikoff (Eds.), Realising REDD+: National Strategy and Policy Options (pp. 25-43). CIFOR, Bogor, Indonesia.

Pham, T. T., Gregorio, M. Di, Carmenta, R., Brockhaus, M. and Le, D. N. 2014. The REDD+ Policy Arena in Vietnam: Participation of Policy Actors. Ecology and Society, 19(2).

Scharpf, F. W. 1997. Games Real Actors Play. Actorcentered Institutionalism in Policy Research. Boulder, Colorado: Westview.
Scharpf, F. W. 2000. Institutions in Comparative Policy Research. Comparative Political Studies, 33(6-7): 762790. doi:10.1177/001041400003300604

Schroeder, H. and McDermott, C. 2014. Beyond Carbon: Enabling Justice and Equity in REDD + Across Levels of Governance. Ecology and Society, 19 (1): 2-4.

Sherpa P. D. and Rai, T.B. 2013. Experience of Nepali Indigenous Peoples on Free, Prior and Informed Consent (FPIC). Journal of Forest and Livelihood, 11(2): 82-86.

Somorin, O. A., Visseren-Hamakers, I. J., Arts, B., Sonwa, D. J. and Tiani, A. M. 2014. REDD+ Policy Strategy in Cameroon: Actors, Institutions and Governance. Environmental Science and Policy, 35: 87-97.

UN-REDD. 2011. The UN-REDD Programme Strategy (2011-2015). United Nations REDD Programme.

UN-REDD. 2014. Understanding Drivers and Causes of Deforestation and Forest Degradation in Nepal: Potential Policies and Measures for REDD+. (www.tinyurl.com/nepal-drivers-redd accessed on 7 December, 2014).

Vaccaro, I. and Beltran, O. 2010. Conservationist Governmental Technologies in Western European Mountains: The Unfinished Transformations of the Pyrenees. Journal of Political Ecology, 17: 2841. 